\title{
Device Agglutination Problem
}

National Cancer Institute

\section{Source}

National Cancer Institute. Device Agg/utination Problem. NCI Thesaurus. Code C92026.

The device affects the ability of the blood to clot which may be induced by chemical, mechanical, or thermal properties of the device. 